\title{
A REVIEW INPUT FACTORS ELASTICITY AND RETURN TO SCALE OF COOPERATIVE: A SURVEY ON INDONESIAN SAVINGS-LOAN COOPERATIVES
}

\author{
Johnny Walker Situmorang \\ Ministry of Cooperative and SMEs Rol, Indonesia \\ E-mail: jwalker@situmorang.web.id
}

Submission: $27 / 04 / 2018$

Revision: 02/05/2018

Accept: 14/05/2018

\section{ABSTRACT}

This study aims to reveal the production function, return to scale, and production factors elasticity of cooperative by using Indonesia financial service cooperative (IFSC) which has a single business in the field of financial service as a sample of research. Using panel data, this study results both labour and capital factors have a significant influence IFSC production. The IFSC industry condition is increasing return to scale (IRS). Production elasticity of capital is higher than labour force so that IFSC business expansion is faster with increasing IFSC capital. The cooperative financial services industry condition is increasing return to scale that enables IFSC business expansion. Given the availability of IFSC resources and its operating environment, IFSC's business expansion strategy should be more labour-intensive than capitalintensive, employing more labour than capital. The government should provide support for improving human resource capacity.

Keywords: cooperative, production function, return to scale, elasticity JEL classification: C51, D01, D24 
INDEPENDENT JOURNAL OF MANAGEMENT \& PRODUCTION (IJM\&P)

http://www.ijmp.jor.br

v. 9 , n. 4, October - December 2018

ISSN: 2236-269X

DOI: 10.14807/ijmp.v9i4.832

\section{INTRODUCTION}

As a business entity, the Indonesia cooperative operates as a non-cooperative entity, such as a limited company. Legality of the existence of Indonesian cooperatives engaged in the field of financial services is the Act 25 of 1992 on Cooperatives and Government Regulation No. 9 of 1995 on the Implementation of Savings and Loan Cooperative Business.

The distinguish cooperatives with non-cooperative enterprises is the social content based on cooperative principles that show ownership of cooperatives with membership systems, and the dimensions of democracy in decision-making based on "one man one vote" in the Meeting of Members. The Indonesian cooperatives content a social dimension with principles in conducting business that aims to enhance their members' welfare (SWASONO, 1988, 2015).

Cooperatives are inclusive financial institutions because of their direct involvement in creating financial access of the poor and low-income people (MUBYARTO, 1988; MUNKER, 1997; NASUTION, 1990; RAHARJO, 2010a, 2010b; SITUMORANG, 1985, 2011a, 2014).

IFSC has been massively operating in rural and urban areas involving millions of people both as members of the IFSC as well as the community so-called inclusive finance. Until 2015, the number of active cooperatives in the country reached 150,223 units with 37.78 million members or 252.49 members per cooperative and they created business transactions amounted to IDR266.13 trillion (USD19.71 billion) with total assets of IDR242.45 trillion (USD17.96 billion).

They employed 537,234 people or 3.38 people per cooperative with productivity reached IDR495.37 million (USD36,694.13) per worker (SITUMORANG, 2017a, 2017b). IFSCs raise public funds, particularly from it members, and redistribute the funds for productive, consumptive, and investment financing. Source of fund from banking is limited because interest rate relatively high (SITUMORANG, 2007).

IFSC gets revenues on loan services and pays expenses on collected funds. Therefore, the production process must be efficient so that IFSC able to compete in competitive money market. Estimation of production function is one way to improve efficiency. The problem of this research is how IFSCs production function. 
INDEPENDENT JOURNAL OF MANAGEMENT \& PRODUCTION (IJM\&P)

http://www.ijmp.jor.br

v. 9 , n. 4, October - December 2018

ISSN: 2236-269X

DOI: 10.14807/ijmp.v9i4.832

This study aims to determine the production function of IFSC and its estimation reveals the elasticity of production and economics scale of financial services industry cooperative Indonesia. The results of this research will be useful for improving the efficiency of IFSC and as input for the government to formulate the regulation, policy, and strategy of IFSC development towards global market.

\section{LITERATURE REVIEW}

Revealing elasticity of production factors and economic scale is very interesting in microeconomics and practices. Using production function, we can find both the elasticity of factors and economic of scale.

The previous studies which investigated return to scale related to the economies of scale of microfinance institutions suggested that microfinance institutions such as credit unions (CUs) and cooperatives need to scale up in order to increase their efficiency. This is related to the nature of the institutions which are not entirely profit seekers.

Zacharias (2008) has examined the scalability of microfinance institutions globally and found that operational efficiencies are positively correlated with firm size, which means that bigger microfinance institutions are associated with smaller average costs.

Bolli and Anh (2012) used a production function approach with the same panel data, and their findings suggest that microfinance institutions need to either grow or merge in order to exploit its potential source of efficiency gains due to its increasing return to scale.

Hartarska, et al. $(2012,2013)$ have also identified an increasing return to scale and input price elasticity of microfinance institutions and suggested the needs of the institutions to grow or consolidate in order to benefit from lower average costs. An empirical study by Chen (2017) that examined the economies of scale of CUs in the United States also shows that larger CUs are operated more efficiently than their smaller counterparts are in term of operating cost. The economics of scale does matter to higher efficiency of microfinance institution.

Despite various previous studies on the economies of scale of microfinance institutions, there are still few studies which are specifically focused on cooperatives or CUs. Koot (1978) investigated the economics return to scale of United States CUs 
INDEPENDENT JOURNAL OF MANAGEMENT \& PRODUCTION (IJM\&P)

http://www.ijmp.jor.br

v. 9, n. 4, October - December 2018

ISSN: 2236-269X

DOI: 10.14807/ijmp.v9i4.832

by using a derivation of Cobb-Douglas function. It shows that CUs, unlike the banking institution, were subject to a decreasing return to scale.

Wolken and Navratil (1980) challenged this Koot's model by including the factor price with wage rate, and it shows that CUs reap small but statistically significant economies of scale. A recent study by Hartaska, et al. (2012), that used global data of cooperatives to examine the nature of this industry, has identified that the cooperatives run at an increasing return to scale that leads consolidation or expansion among the players in order to lower the cost.

There were previous studies on cooperatives in Indonesia which have used cost functions to estimate the efficiency and scale of the industry. Situmorang (1989) found that the rural bank industry in Indonesia operated on a decreasing cost to scale. Similarly, multi-business village unit co-operatives (VUCs) operated on a decreasing cost to scale (SITUMORANG, 1989, 1991, 2010, 2011b, 2011c, 2013).

The result study of Situmorang (2018) with using Learning Curve model revealed that Indonesian financial services cooperative is in condition increasing cost to scale but still relatively efficient.

\section{ANALYTICAL FRAMEWORK}

In the competitive market, a business entity always strives to maximize profit or minimize the cost. On the perspective of microeconomics, business efficiency can be explained by examining both their production side and their cost side (KOUTSOYIANNIS, 1982).

The economic scale analysis is useful to sketch the nature of an industry when the average business size of firms in the industry increases if a double of production inputs and determines the competitiveness of the industry. This theory is valid in the real world, but to test it, data must be available (NICHOLSON, 1979).

The production side approach estimates the efficiency through production function, while the cost side approach estimates the cost function. The return to scale describes the output response to a proportionate increase of all input. Returns to scale are easily defined for homogeneous production functions (HENDERSON; QUANDT, 1980). Assume using inputs $X_{1}$ and $X_{2}$, thus

$$
Q=f\left(t X_{1}, t X_{2}\right)=t k f\left(X_{1}, X_{2}\right)
$$


INDEPENDENT JOURNAL OF MANAGEMENT \& PRODUCTION (IJM\&P)

http://www.ijmp.jor.br

v. 9, n. 4, October - December 2018

ISSN: 2236-269X

DOI: 10.14807/ijmp.v9i4.832

where $\mathrm{t}$ is positive real number and $\mathrm{k}$ is a constant. If both inputs are increased by the factor $t$, output is increased by the factor $t^{k}$. If output increases by the same proportion, return to scale are constant. They are increasing if output increases by a greater proportion and decreasing if it increases by smaller proportion.

Returns to scale increasing if $k>1$, costant if $k=1$, and decreasing if $k<1$. Homogeneous production function satisfies the condition of the degree of homogeneity by Euler's theorem $\varepsilon_{1}+\varepsilon_{2}=\mathrm{k}$. The increasing return to scale (IRS) shows the economies of scale with high economic power (Gelles and Mitchell, 1996).

The production function with homogeneous of degree one is known by CobbDouglas Production Function (CDPF). Homogeneity of degree one is often assumed for production function and the long-run production function is assumed as a homogeneous to degree one. Allen (1956) had made mathematical properties of production function homogeneous to degree one.

Econometrics makes it easy to analyze the production process. Euler's theorem can be used to determine the symmetry of the stages of the production for the input that is assumed variable in the short-run and the input that is assumed fixed in the short run. Marginal product of factors is diminishing and less than average products in the stage-2, namely rational region (DOLL; ORAZEM, 1984).

Economies or diseconomies of size refer to the impact of output expansion upon average cost. The inputs are combined along the long-run expansion path in any ratio that minimizes the cost at each level of output. If the production functions exhibit indivisibilities or smoothly increasing return to scale, a technical externality exists.

The increasing return to scale and perfectly competitive input markets, average cost declines over the relevant range. A technical externality causes market failure either because it leads to monopoly or because free competitive enterprise is not viable at marginal cost price (FERGUSSON; COULD, 1975).

\section{METHOD OF ANALYSIS}

The disclosure of the production function of the IFSCs in this research is using the approach of microeconomics, statistical, and econometric analysis (HILL et al., 2012). Generically, the production function is a power function and the input factors 
INDEPENDENT JOURNAL OF MANAGEMENT \& PRODUCTION (IJM\&P)

http://www.ijmp.jor.br

v. 9, n. 4, October - December 2018

ISSN: 2236-269X

DOI: 10.14807/ijmp.v9i4.832

affecting output. According to this theory, the production function is shown by the following general equation model

$$
Q=f(L, K, M, \ldots, . .)
$$

where $Q$ is the output that influenced by input factors $L$ (labor), K (capital), M (material), and so on. If using inputs $L$ and $K$, the power function of equation is

$$
\mathrm{Q}=A L^{\alpha} K^{\beta}
$$

where " $A$ " is the estimated coefficient technology and parameters $\alpha$ and $\beta$ are the estimated coefficient of inputs of $L$ and $K$. The equation (3) is non-linear function can be transformed to be linear function by Ln - Ln model, that is

$$
\operatorname{LnQ}=\ln A+\alpha \ln L+\beta \ln K
$$

In this research, we use inputs $L$ and $K$, so the equation (4) is applied to estimate the IFSC production function where unit of $Q$ is loans in IDR million, $L$ is outpouring of man hours $(\mathrm{MH})$, and $\mathrm{K}$ is equity in IDR million, ceteris paribus. The elasticity of IFSC inputs production are

$$
\partial \ln Q / \partial \ln F_{i}=\varepsilon_{i}
$$

where $\mathrm{F}_{\mathrm{i}}$ is the factors $\mathrm{i}$ of $\mathrm{L}$ and $\mathrm{K}$. The economics of scale is determined based on Euler's theorem by

$$
\sum \varepsilon_{i}=\alpha+\beta
$$

If $\varepsilon_{i}<1$, that is decreasing return to scale (DRS), $\varepsilon_{i}=1$ is constant return to scale (CRS), and $\varepsilon_{i}>1$ is increasing return to scale (IRS).

Business planning bases on business growth can be derived by the equation (3). The growth model is

$$
\mathrm{Gq}=\varepsilon_{\mathrm{lg}}+\varepsilon_{\mathrm{k}} \mathrm{g}_{\mathrm{k}}
$$

where $\mathrm{Gq}$ is the total growth of business, $\mathrm{g}_{\mathrm{l}}$ and $\mathrm{g}_{\mathrm{k}}$ are the growth of $\mathrm{L}$ and $\mathrm{K}$, respectively.

The economic efficiency is to maximize profit by constraint budget. To determine economic efficiency is to use the following equation by La-grange multiplier, that is

$$
\operatorname{Max} L a=A L^{\alpha} K^{\beta}+X\left(C_{0}-W L-r K\right)
$$


INDEPENDENT JOURNAL OF MANAGEMENT \& PRODUCTION (IJM\&P)

http://www.ijmp.jor.br

v. 9, n. 4, October - December 2018

ISSN: 2236-269X

DOI: 10.14807/ijmp.v9i4.832

where $\lambda$ is La-grange multiplier, $C_{0}$ is constraint budget, $w$ is nominal wage of labor, and $r$ is rent of capital. Equation (9) will drive efficiency condition using each input production, that is

$\mathrm{VMP}_{\mathrm{i}}=\mathrm{r}_{\mathrm{i}}$

or

$\mathrm{PqMP}_{\mathrm{i}}=\mathrm{r}_{\mathrm{i}}$

where VMPi is value of marginal product of input $i, r_{i}$ is rent (price) of input $i$, that is nominal wage $(\mathrm{W})$ and rent $(\mathrm{r}), \mathrm{P}_{\mathrm{q}}$ is price of output, and $\mathrm{MP}_{\mathrm{i}}$ is marginal product of input i. The equation (10) denotes input factors demand function.

To profit maximize, equation (8) derivates the function of the expansion path of business, ie

$$
K=f(L)
$$

or

$$
K=\delta L
$$

where $\delta$ is the relation coefficient of $\mathrm{K}$ and $\mathrm{L}$, ratio capital and labor or marginal capital related labor for expansion.

\section{DATA}

To operate equation (4), the data used is secondary data from the survey in 2014. The secondary data sourced from formal reports of each sample cooperative in The Annual Cooperative Board Accountability Report (ACBAR) in 2011 - 2013. Data in the form of data panel, namely combined cross section data from 39 IFSCs samples and time series data 2011 - 2013, so that available 117 units of data observation.

The sample selection is based on the distribution and variety of IFSCs in several provinces of Indonesia, namely North Sumatra, Central Java, West Kalimantan, Central Sulawesi, and East Nusa Tenggara. Sampling technique through IFSCs sample frame with simple random sampling which registered. Data processing based on the software Eviews which appropriates to process the data panel (AGUNG, 2009).

\section{RESULTS OF RESEARCH}

\subsection{Sample performance}


INDEPENDENT JOURNAL OF MANAGEMENT \& PRODUCTION (IJM\&P)

http://www.ijmp.jor.br

v. 9, n. 4, October - December 2018

ISSN: 2236-269X

DOI: 10.14807/ijmp.v9i4.832

Table 1 shows the statistical performance of the FSC sample in this study. During 2011 - 2013, the average outpouring of worker is 65.211.90 man-hours per year with the lowest of $1,824.0$ man-hours and a maximum of 893,760.0 man-hours. The employment outpour is equal to the employment of 465.8 workers per cooperative.

The use of FSC capital for production process is an average of IDR17,535.56 million (USD1.3 million) per annum with a minimum capital of IDR12.07 million (USD894,074.0) and a maximum of IDR267,822.63 million (USD1.3 million). The use of labor and capital resulted in output per FSC on average of IDR44.118.16 million (USD3.27 million) with a minimum output of IDR6.30 million (USD466,667.0) and a maximum of IDR1,015,638.06 million (USD75.23 million).

The performance of labor, capital, and output of FSC is very varied with the coefficient of variation each more than $200 \%$. That is, the spread of data of each object is very far from the average value. The high diversity of research and resource areas is shown by skewness and positive value data kurtosis which means the distribution is not norm or not symmetrical and the data distribution is leaning to the left where the mean value is greater than the median. The overall performance of the sample based on IFSC labor, capital, and output is seen in Appendix-1.

Table 1: Descriptive Statistical Performance of IFSC Sample, Years 2011 - 2013

\begin{tabular}{|l|r|r|r|}
\hline \multicolumn{1}{|c|}{ Items } & \multicolumn{1}{c|}{$\begin{array}{c}\text { L } \\
\text { (MH) }\end{array}$} & \multicolumn{1}{c|}{$\begin{array}{c}\text { K } \\
\text { (IDR million) }\end{array}$} & \multicolumn{1}{c|}{$\begin{array}{c}\text { Q } \\
\text { (IDR million) }\end{array}$} \\
\hline Average & $65,211.90$ & $17,535.56$ & $44,118.16$ \\
\hline Minimum & $1,824.00$ & 12.07 & 6.30 \\
\hline Maximum & $893,760.00$ & $267,822.63$ & $1,015,638.06$ \\
\hline Standard of Deviation & $130,381.56$ & $44,642.73$ & $149,581.43$ \\
\hline Skewness coefficient & 4.00 & 3.91 & 5.36 \\
\hline Kurtosis coefficient & 18.76 & 16.19 & 29.66 \\
\hline
\end{tabular}

The money market faced by cooperatives can be shown by the interest expenses and the interest revenue channeled by the IFSC to members and communities or the IFSC lending rates. The difference between interest rates on loans and deposits is the net interest margin (NIM) of IFSC.

The development of interest expense during 2011-2013 is much lower than interest rate and tends to rise. In 2011, the average interest expense per cooperative was $5.38 \%$ per annum, then increased to $6.1 \%$ in 2012, and increased again to $8.81 \%$ in 2013. Average of the cooperative's savings interest rate is $6,76 \%$ a year or $0.56 \%$ 
INDEPENDENT JOURNAL OF MANAGEMENT \& PRODUCTION (IJM\&P)

http://www.ijmp.jor.br

v. 9, n. 4, October - December 2018

ISSN: 2236-269X

DOI: 10.14807/ijmp.v9i4.832

per month. The deposit interest rate is very low, which is why the funds collected in the cooperative are cheap funds.

Unlike the interest expense, the cooperative loan rates are high but tend to decrease during 2011-2013. In 2011, the average interest rate was $29.80 \%$, down to $28.33 \%$, and down again to $24.16 \%$. The average interest revenue rate per annum during this period is $27.43 \%$ or $2.29 \%$ per month. Thus, the margin obtained by the cooperative was $24.41 \%$ in 2011 , then decreased to $22.23 \%$, and decreased again to $15.35 \%$. The average margin rate is $20.66 \%$ a year or $1.72 \%$ per month. Positive developments occurred as margins narrowed and declined, as well as the cost of funding and loan interest fell further. This is also an indication that efficiency and cooperative management are increasing.

Figure 1: Trend of Loan Rate, Cost of Fund, and NIM of Cooperative Sample, Years $2011-2013(\%)$

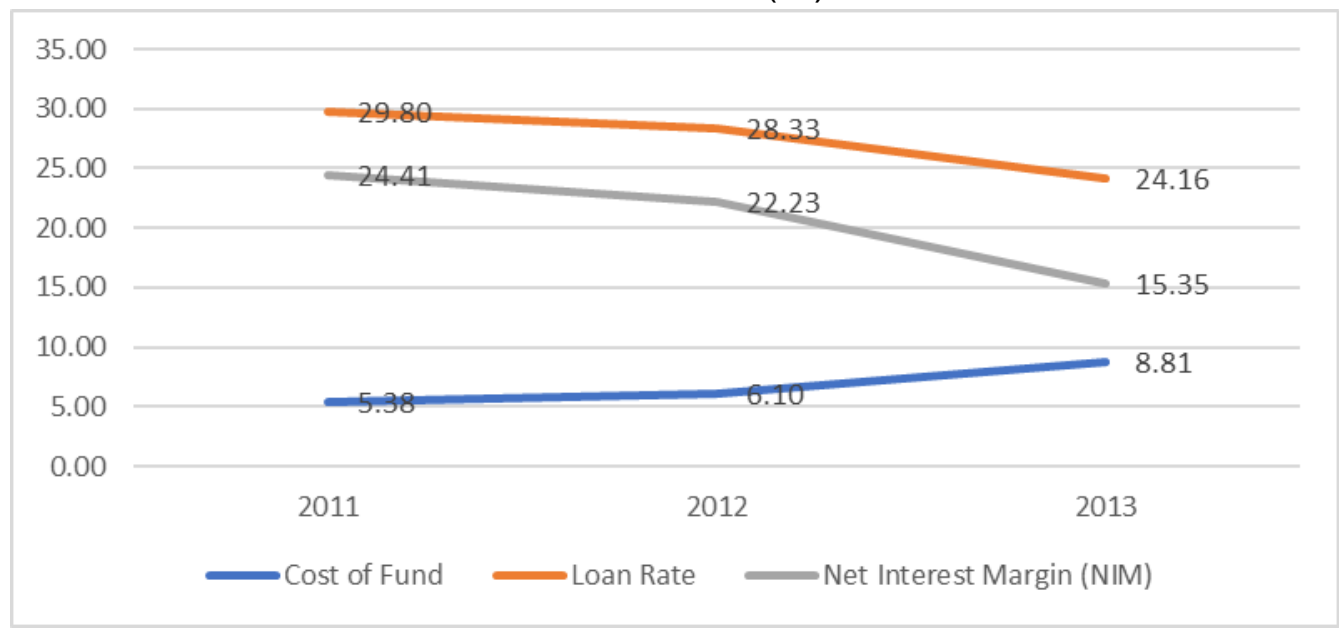

The determination of the interest rate of the IFSCs is the result of the agreement of the member of the cooperative when the Annually Members Meeting (AMM). The AMM is the highest forum of decision-making that should be implemented by board of management of cooperatives.

For members of the cooperative, high interest rates are not disputed by members because they are associated with high risks, the easy procedure of obtaining loans, loyalty, and compensation for saving and borrowing according to the cooperative principles obtained when AMM is exercised. Accessibility to these cooperative finances emphasizes character, capability, and relationships within group members. 
INDEPENDENT JOURNAL OF MANAGEMENT \& PRODUCTION (IJM\&P)

http://www.ijmp.jor.br

v. 9, n. 4, October - December 2018

ISSN: 2236-269X

DOI: 10.14807/ijmp.v9i4.832

\subsection{Estimation of IFSC production function, elasticity, and economic of scale}

Using the equation (4), the estimated IFSC production function is revealed from this study, as shown in Table-2. The estimated validity was very high with R-squared and adjusted R-squared coefficients of 0.8517 and 0.8491 , respectively. That is $84.91 \%$ of data can explain the estimation. Sum squared resid (SSR) or RSS (residual sum square) as a measure of data fit and analysis model. The smaller the RSS, the more suitable data and models.

The data and model match rate is 99.84. Confidence on the estimate is seen at an estimated Likelihood Log value of -156.74. The higher the likelihood log value the stronger the confidence in the factors affecting the output of the cooperative. Hypothesis test shows the overall model estimation is very significant with the value of F-sta of 327.38

Partially, the estimation result of labor and capital has significant effect on cooperative output with probability of $0.00 \%$ far below the error rate (a) $5 \%$. Likewise the constant is significant with $\alpha=2.77 \%$ (t-stat is greater than t-table). The mean predicted dependent variable (output) is 8.2774 or IDR3,933.95 million (US $\$ 291,403.9$ ) per cooperative with standard deviation of 2.4092 or IDR11.13 million (US\$824.08).

Akaike information criterion (AIC) and Schwarz criterion (Bayesian Information Criterion / BIC) are the criteria for selecting estimation models where smaller AICs and $\mathrm{BICs}$ are better model choices. The selection of cost estimation model models for both AIC and BIC are 2,7306 and 2,8014, respectively. The test whether there is autocorrelation with the use of time series data is with Durbin-Watson stat (D-W sta). With D-W stat 0.5927 , no data autocorrelation occurs. With the difference between actual and predicted dependent variables then the estimation accuracy is due to square-error of $26.03 \%$.

Table 2: Estimation of IFSC Production Function

Dependent Variable: LnQ

Method: Panel Least Squares

Sample: 2011-2013 
INDEPENDENT JOURNAL OF MANAGEMENT \& PRODUCTION (IJM\&P)

http://www.ijmp.jor.br

v. 9, n. 4, October - December 2018

ISSN: 2236-269X

DOI: 10.14807/ijmp.v9i4.832

Periods included: 3

Cross-sections included: 39

Total panel (balanced) observations: 117

\begin{tabular}{lrlrr}
\hline \hline \multicolumn{1}{c}{ Variable } & Coefficient & Std. Error & t-Statistic & Prob. \\
\hline \hline \multicolumn{1}{c}{ LnL } & 0.510908 & 0.081158 & 6.295259 & 0.0000 \\
LnK & 0.620338 & 0.045954 & 13.49906 & 0.0000 \\
\multicolumn{1}{c}{ C } & -1.401398 & 0.628250 & -2.230638 & 0.0277 \\
\hline \hline R-squared & 0.851712 & Mean dependent var & 8.277350 \\
Adjusted R-squared & 0.849111 & S.D. dependent var & 2.409200 \\
S.E. of regression & 0.935841 & Akaike info criterion & 2.730563 \\
Sum squared resid & 99.84092 & Schwarz criterion & 2.801388 \\
Log likelihood & -156.7380 & Durbin-Watson stat & 0.592754 \\
F-statistic & 327.3881 & & \\
Prob(F-statistic) & 0.000000 & & \\
\hline \hline
\end{tabular}

From the estimation result in Table 2, production function estimated of IFSC according to equation (4) is

$\operatorname{LnQ}=-1.4014+0.5109 L+0.6203 K$

and its power function as equation (3) is

$\mathrm{Q}=0.2463 \mathrm{~L}^{0.5109} \mathrm{~K}^{0.6203}$

where the coefficient of technology is $0.2463, \varepsilon_{1}=0.5109$, production elasticity of labor, and $\varepsilon_{k}=0.6203$, production elasticity of capital. The equation for growth estimation is

$$
\mathrm{G}_{\mathrm{q}}=0.5109 \mathrm{~g}_{1}+0.6203 \mathrm{~g}_{\mathrm{k}}
$$

To determine the level of economic efficiency depends on budget constraint and the prices of input. From this study, during 2011 - 2013 the cost of IFSC deposits is as the capital price $(r)$ of $6.76 \%$, the wage labor $(w)$ is IDR19,233.0 (USD1.43) per working hour. While the average interest rate of IFSC is $27.43 \%$ per year. If the available budget is IDR100.0 million (USD 7,407,41) then the equation for determining economic efficiency is

$$
\operatorname{Max} \mathrm{La}=0.2463 \mathrm{~L}^{0.5109} \mathrm{~K}^{0.6203}+\mathrm{X}(100,000,000-19,233 \mathrm{~L}-0.0676 \mathrm{~K})
$$

To profit maximize, equation (16) derivates the function of the expansion path of business, ie

$$
\mathrm{K}=19.70 \mathrm{~L}
$$


INDEPENDENT JOURNAL OF MANAGEMENT \& PRODUCTION (IJM\&P)

http://www.ijmp.jor.br

v. 9, n. 4, October - December 2018

ISSN: 2236-269X

DOI: 10.14807/ijmp.v9i4.832

If the budget line increases then the production process changes in the combination of inputs that increase from the previous isoquant. Any additional one man-hour labor outpouring will raise capital by Rp19.70 to keep it efficient.

\section{DISCUSSION}

\subsection{Meaning of production function coefficients estimation}

The estimation result in equation (13) shows CDPF with the function coefficient "A" $=0.2463$ as the technology coefficient. That is, if $L$ and $K$ are each worth zero then the production is amounted of Rp0.2463 or increased production if there is a change in technology.

The production elasticity of labor and capital is 0.5109 and 0.6203 indicating the diminishing marginal product of labor and capital, the value is under one, is within the rational area of its production function. The addition of each one of these factors leads to a smaller increase in production.

The production elasticity of labor force of 0.5109 indicates that each labor input increase by $1 \%$, the production will increase by $0.5109 \%$. Production elasticity of capital of 0.6203 shows a change in capital input of $1 \%$ resulting in additional production of $0.6203 \%$. The capital input is more elastic than labor when changes in inputs occur.

The condition of cooperative financial services industry is Increasing Return to Scale (IRS) because the amount of production elasticity of labor and capital is greater than one, that is $1.1312(=0.5109+0.6203)$. As labor and capital increase by $1 \%$ simultaneously then production increases by more than $1 \%$, ie $1.13 \%$.

The coefficient of business expansion path of $21,597.36$ is the relation dimension of $K$ and $L$. If one unit (man-hour) input $L$ increases then $K$ increases by IDR 21,597.36 (US \$1.6) in order to remain economically efficient. This IFSC industrial study finding is in line with the previous research in abroad.

\subsection{IFSC business expansion and economic efficiency determination}

The condition increasing return to scale of IFSC shows the IFSC industry is on an economies of scale. The large business scale of IFSC is more efficient and competitive than small-scale enterprises. This allows IFSC to enlarge its business 
INDEPENDENT JOURNAL OF MANAGEMENT \& PRODUCTION (IJM\&P)

http://www.ijmp.jor.br

v. 9, n. 4, October - December 2018

ISSN: 2236-269X

DOI: 10.14807/ijmp.v9i4.832

scale continuously. IFSC business planning is evident from the growth of its business. Projected growth of IFSC business as equation (16).

Planning IFSC business development is an indicative planning because it depends on the vision and mission and the availability of corporate resources. Scenarios are visible from business orientation, ie, labor-intensive or capital-intensive scenarios. Labor-intensive scenarios are oriented towards more labor usage so that growth plans are higher than capital growth. While the capital-intensive scenario uses more capital than labor so that the growth plan is bigger than the labor force.

Table 3: IFSCs Business Growth Projection Based on Growth Equation

\begin{tabular}{|c|l|c|c|c|c|c|}
\hline No & $\begin{array}{c}\text { Expansion } \\
\text { Scenarios }\end{array}$ & $\boldsymbol{\varepsilon}_{\mathbf{l}}$ & $\boldsymbol{\varepsilon}_{\mathbf{k}}$ & $\mathbf{g}_{\mathbf{I}}$ & $\mathbf{g}_{\mathbf{k}}$ & $\mathbf{G q}$ \\
\hline 1 & Labor intensive & 0.5109 & 0.6203 & $10 \%$ & $5 \%$ & $10.73 \%$ \\
\hline 2 & Capital intensive & 0.5109 & 0.6203 & $5 \%$ & $10 \%$ & $13.18 \%$ \\
\hline
\end{tabular}

Counted by equation (16)

Table 3 shows the IFSCs business planning scenario based on the estimation of production function. With the production elasticity of labour and capital of 0.5109 and 0.6203 , the labour-intensive growth scenario with $10 \%$ employment growth plan and $5 \%$ growth of capital then the growth of IFSC business is $10.73 \%$.

The scenario of capital-intensive growth with 5\% labor and 10\% capital growths then IFSC business growth is $13.18 \%$. The capital-intensive growth scenario gives higher business growth than labour-intensive growth scenarios because of the influence of capital higher than the labour force on production.

Enterprise management, in accordance with business philosophy that the business always to maximize profit, is generally more likely to choose a capital-based strategic plan in the production process. It is also supported by the ease of procurement of physical capital and its control.

But for companies incorporated as cooperatives, capital factor becomes the main obstacle and faces society with abundant labour. So IFSC as a social business entity should use planning with labour-intensive scenario to expand its business.

The efficiency of the company is seen from the technical and economic sides. Technical efficiency is a necessary condition and economic efficiency as a sufficient condition. From the estimation result of IFSC production function revealed IFSC is in economic efficiency because MPI and MPk it is smaller than one, in rational area of production. 
INDEPENDENT JOURNAL OF MANAGEMENT \& PRODUCTION (IJM\&P)

http://www.ijmp.jor.br

v. 9, n. 4, October - December 2018

ISSN: 2236-269X

DOI: 10.14807/ijmp.v9i4.832

The level of economic efficiency can be known from the Lagrange multiplier with the budget constraint (budget line). The barometer of IFSC competition is the money price in the market and the factor prices of production, labor and capital. Economic efficiency also shows technical efficiency.

According to determine the level of economic efficiency, its depends on budget constraint and the prices of input. The derivation of equation (17) produces an equation of efficiency as equations (10) or (11), and (18), so that the level of input use, production level, and maximum profit can be known.

For example, in the budget of IDR100.0 million (USD7,407.41), the economic efficiency of IFSC is the use of labor force of 4,630.2 man-hour (MH) and capital of IDR161,944,608.0 (USD11,995.8) and output of IDR2,272,423.96.0 (USD168.33). IFSC has achieved maximum profit even though it could be negative profit (loss), zero profit (breakeven), or positive profit (gain).

\section{REMARKS}

From the results of this study can be seen IFSC production function where labour and capital production factors have a significant affect its production. The production elasticity of labour and capital shows the IFSC production process in a rational production area.

But the production elasticity of capital is higher than labour. For the cooperative business expansion, the effect of using capital is greater than using labour. The IFSCS industry is in the condition of the increasing return to scale (IRS) or condition of economies of scale. In the business planning of IFSC, the expansion of cooperative business still gives bigger benefit to cooperatives. The results of this study indicate that the increasing return to scale condition of IFSCs industry is in line with the results of research in various countries.

From these conclusions, IFSC can be an efficient large-scale enterprise. To achieve economies of scale, IFSC management should develop a business continuously to achieve business capacity. By looking at the internal and external environments of the IFSC, it is advisable that IFSC's business development strategy be pursued through labour-intensive to enable cooperatives to absorb local labour and increase the added value of IFSC. The implications of the policy should be that the 
INDEPENDENT JOURNAL OF MANAGEMENT \& PRODUCTION (IJM\&P)

http://www.ijmp.jor.br

v. 9, n. 4, October - December 2018

ISSN: 2236-269X

DOI: 10.14807/ijmp.v9i4.832

government supports the IFSC in improving human resource capacity through employment training.

\section{REFERENCES}

AGUNG, I. G. N. (2009) Time series data analysis using eviews. statistics in practice. John Wiley \& Sons Ltd.

BOLLI, T.; ANH V. T. (2012) On the Estimation Stability of Efficiency and Economies of Scale in Microfinance Institutions (Working Paper). Zurich: KOF Swiss

Economic Institute. Avaliable: https://doi.org/10.3929/ethz-a-006909474. Access: April 24, 2018.

CHEN, SU-JANE. (2017) Does Size Matter? Economies of Scale in the Credit Union Industry. International Journal of Trade, Economics and Finance, v. 8,n. 6, p. 258-262. Available:

http://www.ijtef.org/index.php?m=content\&c=index\&a=show\&catid=88\&id= 916 .

Access: April 24, 2018. doi:10.18178/ijtef.2017.8.6.575.

DOLL, J. P.; ORAZEM, F. (1984) Productions economics. Theory With

Applications, Second Edition. John Wiley \& Sons.

FERGUSON, C. E.; GOULD J. P. (1975) Microeconomic theory, Fourth Edition.

GELLES, G. M.; MITCHELL D. W. (1996) Returns to Scale and Economies of Scale: Further Observations. The Journal of Economic Education, v. 27, n. 3, p. 259-261, Published online: $10 \mathrm{Jul}$ 2014. Available:

https://www.tandfonline.com/doi/abs/10.1080/00220485.1996.10844915. Access: 20 March 2018

HARTARSKA, V.; NADOLNYAK, D.; XUAN S. (2012) Efficiency in Microfinance Cooperatives. American Journal of Development Studies, v. 1, n. 2, p. 52-75. Available: http://ried.unizar.es/index.php/revista/article/viewFile/52/17. Access:

February 8, 2018.

HARTARSKA, V.; XUAN S.; MERSLAND, R. (2013) Scale economies and input price elasticities in microfinance institutions". Journal of Banking \& Finance, v. 37, n. 1, p. 118-131. Available: http:doi:10.1016/j.jbankfin.2012.08.004. Access:

February 8, 2018.

HENDERSON, J. M.; QUANDT, R. E. (1980), Microeconomic theory. A mathematical approach, Third edition. International Student Edition, McGraw-Hill Book Company

HILL, R. C.; GRIFFITHS, W. E.; GUAY C. L. (2012). Principles of Econmetrics, Fourth Edition. International Student Edition. John Wiley \& Sons Australasia Pty, Ltd, Sidney, New York, London, Toronto.

KOUTSOYIANNIS, A. (1982) Modern microeconomics, Second Edition.

KELLER, G. (2005) Statistics for management and economics, 7th Edition, International Student Edition (ISE).

MUBYARTO (1998) Reformasi sistem ekonomi. dari kapitalisme menuju ekonomi kerakyatan. Penerbit Aditya Media. 
INDEPENDENT JOURNAL OF MANAGEMENT \& PRODUCTION (IJM\&P)

http://www.ijmp.jor.br

v. 9, n. 4, October - December 2018

ISSN: 2236-269X

DOI: 10.14807/ijmp.v9i4.832

MUNKER, HANS-H. (1997) Past Present and Future of the Co-operative Business. University of Marburg, Germany. Paper presented at the Asia Pacific Cooperatives and Small \& Medium Enterprises Network Conference, Jakarta: July 14 - 15.

NASUTION, M. (1990) Keragaan koperasi unit desa sebagai organisasi ekonomi perdesaan. Disertasi program Dokor Jurusan Perencanaan Wilayah Perdesaan, Fakultas Pascasarjanan IPB. Bogor.

NICHOLSON, W. (1979) Intermediate microeconomics and its application, Second Edition. The Dryden Press, Hinsdale, Illinois

RAHARDJO, D. (2010a) Ekonomi politik perkoperasian indonesia. Prosiding Seminar Ekonomi Politik Perkoperasian Indonesia. Ibnoe Soedjono Center bekerjasama dengan GKBI.

RAHARDJO, D. (2010b) Koperasi dalam ruang publik. Prosiding Seminar Ekonomi Politik Perkoperasian Indonesia. Ibnoe Soedjono Center bekerjasama dengan GKBI.

SITUMORANG, J. W. (1985) Koperasi dalam pembangunan. Paper Staff Balitbangkop \& PKM.

SITUMORANG, J. W. (1989) Skala ekonomi bank perdesaan. Studi kasus BKPD di Kabupaten Ciamis, Jawa Barat. Tesis Program Magister Sains, Fakultas Pascasarjana IPB, Bogor.

SITUMORANG, J. W. (2007) Sukubunga Perbankan Masih Penghambat Pembiayaan KUKM Indonesia. Infokop-Media Pengkajian KUKM edisi Desember 2007 no 28 tahun XXI; hal 121-131: ISSN: 0126-813X (Akreditasi LIPI). Deputi Bidang Pengkajian UKMK, Kemenneg KUKM. Jakarta.

SITUMORANG, J. W. (2010) Analisis Tipologi dan Posisi Koperasi: Studi Kasus Koperasi Penerima Program Perkassa di Jawa Timur. Proceeding THE 4TH CONFERENCE ON MANAGEMENT RESEARCH. SUSTAINABLE COMPETITIVE ADVANTAGE IN CHALLENGING MARKET ENVIRONMENT; 2010; p1-13: ISSN: 2086-0390; PPM School of Management, Jakarta.

SITUMORANG, J. W. (2011a) Koperasi dan Penanggulangan Kemiskinan di Indonesia: Tinjauan Probabilitas Tingkat Anggota Koperasi dan Tingkat Kemiskinan Provinsi. Jurnal-Pengkajian KUKM September 2011; v. 6, p. 43-69; ISSN 19782896; Deputi Bidang Pengkajian Sumberdaya UKMK, Kementerian KUKM. Jakarta.

SITUMORANG, J. W. (2011b) Estimasi Fungsi Usaha Koperasi Dengan Model Power Function Multiple Regression Terhadap Koperasi Berprestasi Tahun 2009". Prosiding SEMINAR NASIONAL DALAM RANGKA FORUM TAHUNAN PENGEMBANGAN IPTEK NASIONAL (NSTD Forum). Jakarta: LIPI.

SITUMORANG, J. W. (2011c) The Economic of Scale And Scope and Business Diversified of KUD. Paper KONGRES ILMU PENGETAHUAN NASIONAL V 3 - 7 September. Jakarta, 6 September 1991c.

SITUMORANG, J. W. (2013) Uang, Koperasi, Dan Moneterisasi Perekonomian "Akar Rumput". Infokop-Media Pengkajian KUKM Oktober 2013 Edisi v. 23, n. 1: hal 97-113; ISSN 0216-813X (Akreditasi LIPI). Deputi Bidang Pengkajian Sumberdaya UKMK Kementerian KUKM. Jakarta. 
INDEPENDENT JOURNAL OF MANAGEMENT \& PRODUCTION (IJM\&P)

http://www.ijmp.jor.br

v. 9, n. 4, October - December 2018

ISSN: 2236-269X

DOI: 10.14807/ijmp.v9i4.832

SITUMORANG, J. W. (2014) Telaahan Perkembangan Ilmu Ekonomi Global dan Kaitannya dengan Pembangunan Koperasi Indonesia. Paper LAPORAN KINERJA APARATUR SIPIL NEGARA TAHUN 2014. Deputi Bidang Pengkajian Sumberdaya UKMK, Kementerian KUKM. Jakarta, Desember.

SITUMORANG, J. W. (2014) Survai Posisi Strategik Koperasi Menuju Skala Besar. Aplikasi Model McKinsey-GE Terhadap Beberapa Koperasi Calon Skala Besar di Beberapa Provinsi". JurnaL-PKUKM, volume 9, hal 1-22. ISSN 1978-2896. Deputi Bidang Pengkajian Sumberdaya UKMK, Kementerian KUKM. Jakarta, Desember.

SITUMORANG, J. W. (2017a) Peran Koperasi Dalam Perekonomian. Kementerian Koperasi dan UKM RI. ISBN 978-602-5449-02-4. Jakarta.

SITUMORANG, J. W. (2017b) Posisi Strategis Koperasi Jasa Keuangan Sebagai Lembaga Keuangan Inklusif. Kementerian Koperasi dan UKM RI. ISBN 978-6025449-03-1. Jakarta.

SITUMORANG, J. W. (2018) Learning Curve Estimation of Indonesia Financial Service Cooperative. Survey on Indonesia Savings-Loan Cooperative.

International Journal of Small and Medium Enterprises and Business Sustainability, v. 3, n. 01 p. 61-85, March 2018. E-ISSN: 2442-9368. CISBucs University. of Trisakti, Jakarta, Indonesia-University Social Sciences, Warsaw, Poland.

SWASONO, S. E. (1998) Demokrasi Ekonomi: Komitmen dan Pembangunan Indonesia. Pidato PENGUKUHAN JABATAN GURU BESAR TETAP ILMU EKONOMI PADA FAKULTAS EKONOMI UNIVERSITAS INDONESIA. Jakarta, 13 Juli.

SWASONO, S. E. (2015) Pidato Akademis Sambutan Promosi Doktor Untuk Anna A. Susanti. Paper SIDANG AKADEMIS UNIVERSITAS BINA NUSANTARA DALAM RANGKA UJIAN PROMOSI DOKTOR. Universitas Indonesia. Jakarta, 30 Mei.

Wolken, J. D.; Navratil, F. J. (1980) Economies of Scale in Credit Unions: Further Evidence. The Journal of Finance, 35(3), 769. Avalaible: https://onlinelibrary. wiley.com/doi/abs/10.1111/j.1540-6261.1980.tb03497.x. Access: April 24, 2018. doi:10.2307/2327497.

ZACHARIAS, J. (2008) An investigation of Economies of Scale in Microfinance Institutions. Working Paper: GLUCKSMAN INSTITUTE FOR RESEARCH IN SECURITIES MARKETS. New York Avalaible: http://web-docs.stern.nyu.edu/ glucksman/docs/Zacharias2008.pdf. Access: April 24, 2018. 